\title{
Contents
}

149 The Origins of Clerical Celibacy in the Western Church Charles A. Frazee

168 Paris Theologians on War and Peace, 1521-1529

WALTER F. BENSE

186 English Reformation: Product of King or Minister?

JOSEPH D. BAN

198 The Archbishop of Canterbury's Visit to Palestine: An Issue in Anglo-Vatican Relations in 1931

Thomas E. HacheY

208 The Southern Aid Society and the Slavery Controversy

VICTOR B. HOWARD

225 The New American Catholic History

Moses Rischin

230 American Foreign Policy, The Politics of Missions and Josiah Strong, 1890-1900

JAMES E. REED

246 New England Dissent, 1630-1833: A Review Article WILLIAM R. EsteP

\section{Dissertation Abstracts:}

R. Dwayne Connon, The Hierarchy and the Church's Mission in the First Five Centuries

Charles L. Stinger, Humanism and Reform in the Early Quattrocento: The Patristic Scholarship of Ambrogio Traversari (1386-1439)

\section{Book Reviews}

Burkill, T. A., The Evolution of Christian Doctrine Robert L. Watson Girod, Robert, trans., Origene: Commentaire sur l'Evangile selon Matthieu

Robert M. Grant

Hope, D. M., The Leonine Sacramentary: A Reassessment of Its Nature and Purpose

Jordan, David P., Gibbon and $H$ is Roman Empire William G. Rusch

Robinson, James M., and Helmut Koester, Trajectories Through Early Christianity

Bailey, Terence, The Processions of Sarum and the Western Church

Massey H. Shepherd, Jr.

Himelick, Raymond, Erasmus and the Seamless Coat of Jesus .... Robert G. Kleinhans

Pullan, Brian, Rich and Poor in Renaissance Venice: The Social Institutions of a Catholic State, to 1680

Anne J. Schutte

Bainton, Roland, Women of the Reformation in Germany and Italy ........ Jill Raitt

Dillenberger, John, ed., John Calvin: Selections from His Writings

John H. Leith

Jordan, Wilbur K., Edward VI, The Threshold of Power: The Dominance of the Duke of Northumberland, 1549-15ss

Maurer, Wilhelm, Kirche und Geschichte: Gessamelte Aufsätze. 2 Vols.

Melanges d'Histoire du XVIe Siele; Offerts d Henri Meylan

Meyer, Carl S., ed., Sixteenth-Century Essays and Studies. Vol. I 
Montgomery, John W., In Defense of Martin Lulher Egil Grislis Porter, H. C., ed., Puritanism in Tudor England

Bearisbrick, J. J., Henry $V I I$ John B. Macauley

Steinmetz, David, Reformers in the Wings Allen B. Birchler rauss, Gerald, ed., Manifestations of Discontent in Germany on the Eve of the Reformation

Tedeschi, John A., comp., The Literature of the Italian Reformation

Tonkin, John, The Church and the Secular Order in Reformation Thought

Robert L. Watson Elisabeth G. Gleason hite, B. R., The English to the Pilgrim Fathers ...................................................... Dewey D. Wallace, Jr.

Wolgast, Eike, Dio Wittenbergor Luther-Ausgabe. Zur tberlieferungsgeschichte der Werke Luthers im 16. Jahrhundert ............................ Gottfried G. Krodel

Barth, Hans-Martin, Atheismus und Orthodoxie: Analysen und Modello christlicher Apologetite im 17. Jahrhundert ................................ Jaek Forstman

Hill, Christopher, Antichrist in Seventeenth-Century England .... Dale A. Johnson

Mueller, Janel M., ed., Donne's Prebend Sermons .................... Arthur O. Roberts

Bernard, Paul P., Jesuits and Jacobins: Englightenment and Enlightened Despotism in Austria

Halevy, Elie, The Birth of Methodism in England ...................... J. Hamby Barton

Akenson, Donald, H., The Church of Ireland: Ecclesiastical Reform and Bevolution, $1800 \cdot 1885$

Altholz, Josef L., and Damian McElrath, eds., The Correspondence of Lord Acton and Riohard Simpson. Vol. I ............... Samuel M. Garrett

Bazant, Jan, Alienation of Church Wealth in Mexico: Social and Economio Aspects of the Liberal Revolution, 1856-1875 ....................... William Lux

Brazill, William J., The Young Hegelians ............................................ B. A. Gerrish

Davis, Richard W., Dissent in Politic8, 1780-1830: The Political Life of William Smith, MP

Lewis A. Dralle

Wigmore-Beddowes, Dennis G., Yesterday's Radicals: A Study of the Affinity between Onitarianism and Broad Church Anglicanism in the Nineteenth Century

R. W. Greaves

Allen, Richard, The Social Passion: Religion and Social Reform in Canada, $1914-18$

Tom Faulkner

Fireside, Harvey, Icon and Swastika: The Russian Orthodox Church under Nasi and Soviet Control ............................................ George W. Morrel

Fletcher, William C., The Russian Orthodox Church Dnderground, $191 \%-1970$

Francis M. Donahue

Marshall, Richard H., Thomas E. Bird, and Andrew Q. Blane, eds., Aspects of Religion in the Soviet Union, 1917-1967 .............. George W. Morrel

Wadensjö, Bengt, Toward a World Iutheran Communion: Developments in Lutheran Cooperation up to 1929 ...................................... E. Theodore Bachmann

Burr, Nelson R., Religion in American Life ......................................... Martin E. Marty

Handy, Robert T., A Christian America: Protestant Bopes and Historical Realities

William G. McLoughlin

Marty, Martin E., Righteous Empire: Tho Protestant Experience in America ............................................................................................... Jr.

Schappes, Morris U., ed., A Documentary History of the Jews in the United States, 1654-1875 ........................................................ Joseph L. Blan

Danker, William J., and Wi Jo Kang, eds., The Future of the Christian World Mission: Studies in Honor of $R$. Pierce Beaver .... C. Howard Hopkins

Enns, Arno W., Man, Milieu and Mission in Argentina: $A$ Closo Look at Church Growth

David F. D'Amico

Grabill, Joseph L., Protestant Diplomacy and the Near East: Missionary Influence on American Policy, 1810-1987

Haddad, Robert M., Syrian Christians in a Muslim Society: An Interpretation

Laird, M. A., ed., Bishop Heber in Northorn India: Selections from Heber's Journal

Podipara, Placid J., The Thomas Christians Kenneth L. Crose

Robert I. Burns Virgil A. Olson Charles J. Speel 